\title{
Effects of Green Manure Application and Prolonging Mid-Season Drainage on Greenhouse Gas Emission from Paddy Fields in Ehime, Southwestern Japan
}

\author{
Yo Toma ${ }^{1, *}$, Nukhak Nufita Sari ${ }^{2}$, Koh Akamatsu ${ }^{3}$, Shingo Oomori ${ }^{1}$, Osamu Nagata ${ }^{4}$, \\ Seiichi Nishimura ${ }^{5}$, Benito H. Purwanto ${ }^{2}$ and Hideto Ueno ${ }^{1}$ (D) \\ 1 Graduate School of Agriculture, Ehime University, 3-5-7, Tarumi, Matsuyama 790-8566, Ehime, Japan; \\ housaku423@gmail.com (S.O.); uenoh@agr.ehime-u.ac.jp (H.U.) \\ 2 Faculty of Agriculture, Universitas of Gadjah Mada, Bulaksumur, Yogyakarta 55281, Indonesia; \\ nukhak.nufita.sari@gmail.com (N.N.S.); benito@ugm.ac.id (B.H.P.) \\ 3 Faculty of Agriculture, Ehime University, 3-5-7, Tarumi, Matsuyama 790-8566, Ehime, Japan; \\ kohevergreen@gmail.com \\ 4 NARO Tohoku Agricultural Research Center, 4 Akahira, Shimokuriyagawa, Morioka 020-0198, Iwate, Japan; \\ nagaosa@affrc.go.jp \\ 5 NARO Hokkaido Agricultural Research Center, 1, Hitsujigaoka, Toyohira-ku, Sapporo 062-8555, Hokkaido, \\ Japan; ssnn@affrc.go.jp \\ * Correspondence: toma@agr.ehime-u.ac.jp; Tel.: +81-89-946-9815
}

Received: 8 January 2019; Accepted: 24 January 2019; Published: 1 February 2019

\begin{abstract}
Green manure application helps maintain soil fertility, reduce chemical fertilizer use, and carbon sequestration in the soil. Nevertheless, the application of organic matter in paddy fields induces $\mathrm{CH}_{4}$ and $\mathrm{N}_{2} \mathrm{O}$ emissions. Prolonging mid-season drainage reduces $\mathrm{CH}_{4}$ emissions in paddy fields. Therefore, the combined effects of green manure application and mid-season drainage prolongation on net greenhouse gas emission (NGHGE) were investigated. Four experimental treatments were set up over a 2-year period: conventional mid-season drainage with (CMG) and without (CM) green manure and prolonged (4 or 7 days) mid-season drainage with (PMG) and without (PM) green manure. Astragalus sinicus L. seeds were sown in autumn and incorporated before rice cultivation. No significant difference in annual $\mathrm{CH}_{4}$ and $\mathrm{N}_{2} \mathrm{O}$ emissions, heterotrophic respiration, and NGHGE between treatments were observed, indicating that green manure application and mid-season drainage prolongation did not influence NGHGE. $\mathrm{CH}_{4}$ flux decreased drastically in PM and PMG during mid-season drainage under the hot and dry weather conditions. However, increasing applied carbon increases NGHGE because of increased $\mathrm{CH}_{4}$ and Rh. Consequently, combination practice of mid-season drainage prolongation and green manure utilization can be acceptable without changing NGHGE while maintaining grain yield in rice paddy fields under organically managed rice paddy fields.
\end{abstract}

Keywords: Oryza sativa; Astragalus sinicus; methane; nitrous oxide; heterotrophic respiration; net greenhouse gas emission; mid-season drainage; weed

\section{Introduction}

Global climate change is caused by increasing atmospheric concentrations of greenhouse gases (GHG) such as carbon dioxide $\left(\mathrm{CO}_{2}\right)$, methane $\left(\mathrm{CH}_{4}\right)$, and nitrous oxide $\left(\mathrm{N}_{2} \mathrm{O}\right)$ [1]. As rapid climate change will significantly affect food security and other social issues, mitigation strategies for anthropogenic GHG emissions are required worldwide. 
Rice (Oryza sativa L.) is a major cereal crop. In 2010, rice production in east-, southeast-, and south Asia was $633 \mathrm{Mt}$ from $143 \mathrm{Mha}$. This area constitutes approximately $88 \%$ of all rice paddy fields worldwide [2]. $\mathrm{CH}_{4}$ emissions are the main source of GHG from rice paddy fields. In waterlogged paddy fields, $\mathrm{CH}_{4}$ is generated by anaerobic decomposition of organic matter in the soil [3,4]. In Japan, paddy fields comprised $54.4 \%$ of the total agricultural area in 2017. An estimated $17,904 \mathrm{Tg} \mathrm{CO}_{2} \mathrm{eq}$ of $\mathrm{CH}_{4}$ was emitted from paddy fields in 2014 and it contributed $46.6 \%$ of the $\mathrm{CH}_{4}$ emission in the entire agricultural sector in Japan. $\mathrm{N}_{2} \mathrm{O}$ emission from paddy fields is also considered as a source of atmospheric $\mathrm{N}_{2} \mathrm{O}$ [5]. However, year-round monitoring in a recent study indicated that paddy fields could also be a significant $\mathrm{N}_{2} \mathrm{O}$ sink [6,7]. Therefore, long-term studies of $\mathrm{N}_{2} \mathrm{O}$ emission from paddy fields are necessary because short-term experiments do not provide enough data to evaluate net $\mathrm{N}_{2} \mathrm{O}$ emissions $[5,8]$. Paddy fields have been reported as an atmospheric carbon sink $[9,10]$ and a contributor to global warming owing to their high $\mathrm{CH}_{4}$ emission levels when both soil carbon and $\mathrm{CH}_{4}$ are considered [5]. Therefore, the $\mathrm{CH}_{4}, \mathrm{~N}_{2} \mathrm{O}$, and carbon budget must be considered when evaluating the contribution of paddy fields to global warming.

Green manure (legume crops) application in paddy fields supplies nitrogen required for rice growth and increases soil organic carbon, thus maintaining soil fertility [11]. Green manure seeds are sown after rice cultivation and incorporated into the soil several weeks or months before the next rice planting. Although it improves rice yield, green manure application increases $\mathrm{CH}_{4}$ emissions [12,13]. Toma et al. [14] reported that the incorporation of green manure, in the case white clover (Trifolium repens), into paddy fields induced higher $\mathrm{CH}_{4}$ emissions. In paddy fields, incorporation of organic matter in spring induces higher $\mathrm{CH}_{4}$ emissions during the growing season compared to incorporation in autumn. The reason is that labile organic carbon, which can be the carbon source for $\mathrm{CH}_{4}$ production, is poorly decomposed due to the short time interval between the green manure incorporation and rice cultivation [3]. Green manure applications in paddy fields also increase $\mathrm{N}_{2} \mathrm{O}$ emissions [14]. Therefore, it is necessary to develop rice cultivation techniques that mitigate $\mathrm{CH}_{4}$ emissions and utilize green manure effectively.

Mid-season drainage is successful management practice for mitigating $\mathrm{CH}_{4}$ emissions in paddy fields [15]. Soil oxidation during rice cultivation effectively lowers $\mathrm{CH}_{4}$ emissions. Nevertheless, it can also inhibit the reduction of $\mathrm{N}_{2} \mathrm{O}$ to $\mathrm{N}_{2}$ through denitrification. Zou et al. [16] reported that the introduction of mid-season drainage during rice cultivation reduces $\mathrm{CH}_{4}$ and induces $\mathrm{N}_{2} \mathrm{O}$ emissions. Because $\mathrm{N}_{2} \mathrm{O}$ is a more potent GHG than $\mathrm{CH}_{4}$, it is necessary to balance $\mathrm{CH}_{4}$ decrease and $\mathrm{N}_{2} \mathrm{O}$ increase when introducing mid-season drainage to mitigate GHG emissions in paddy fields. In paddy fields where mid-season drainage has already been introduced, its prolongation mitigates $\mathrm{CH}_{4}$ emissions. Itoh et al. [17] reported that $\mathrm{CH}_{4}$ and $\mathrm{N}_{2} \mathrm{O}$ emissions from paddy fields were suppressed to approximately $72 \%$ (as global warming potential [GWP]-based $\mathrm{CO}_{2}$ equivalent) when mid-season drainage was prolonged.

The aims of this study were to evaluate the effects of green manure application and mid-season drainage prolongation on GHG emissions from paddy fields. The effects of management practices on global warming were evaluated using net GHG emissions (NGHGE) which took into account $\mathrm{CH}_{4}$ and $\mathrm{N}_{2} \mathrm{O}$ emissions and carbon budgets.

\section{Materials and Methods}

\subsection{Study Site}

A 2-year experiment was conducted at the Ehime University Farm $\left(33^{\circ} 57^{\prime} \mathrm{N}, 132^{\circ} 47^{\prime} \mathrm{E}, 12 \mathrm{~m}\right.$ asl) from October 2013 to September 2015. The mean annual air temperature was $16.5^{\circ} \mathrm{C}$ and annual precipitation was $1315 \mathrm{~mm}$ (mean values over a 30-year period from 1981 to 2010). The soil was a fluvic paddy soil classified according to Soil Classification System of Japan [18]. The surface soil layer (approximately 0-21 cm depth) had a sandy clay loam texture (62.6\% sand, 10.9\% silt, 26.5\% clay), with a bulk density of $1.11 \mathrm{~g} \mathrm{~cm}^{-3}$, total carbon concentration of $1.04 \%$, and total nitrogen concentration of 
$0.10 \%$. Free iron $(\mathrm{Fe})$ concentrations were $3.46 \mathrm{~g} \mathrm{Fe} \mathrm{kg}^{-1}$, cation exchange capacity was $8.77 \mathrm{cmol}_{\mathrm{C}} \mathrm{kg}^{-1}$, soil mass carbon in the top $30 \mathrm{~cm}$ of soil was $2.72 \mathrm{~kg} \mathrm{C} \mathrm{m}^{-2}$.

\subsection{Treatments and Management Practices}

In October 2013, four treatments were set up: conventional water management with (CMG) or without (CM) green manure application and prolonged mid-season drainage with (PMG) or without $(\mathrm{PM})$ green manure application. Each treatment consisted of four plots $(2.5 \mathrm{~m}$ wide $\times 8.3 \mathrm{~m}$ long; area $20.8 \mathrm{~m}^{2}$ ). Weed can grow well in the spring season in all the plots because those plots have been used for the study of organic farming for recent decades.

Field management practice was shown in Table 1. Rice straw (6-cm-long segment) was prepared from the residue of rice grown in 2013 and 2014; it was broadcasted and incorporated into the soil surface $\left(0-10 \mathrm{~cm}\right.$ ) at the rate of $5480 \mathrm{kgDW} \mathrm{ha}^{-1}$ (and $2310 \mathrm{~kg} \mathrm{C} \mathrm{ha}^{-1}$ ) in the first year and $2740 \mathrm{kgDW} \mathrm{ha}^{-1}\left(1120 \mathrm{~kg} \mathrm{C}^{-1}\right)$ in the second year. Chinese milk vetch (Astragalus sinicus L.) seeds were manually broadcasted ( $30 \mathrm{~kg} \mathrm{ha}^{-1}$ in 2013 and $40 \mathrm{~kg} \mathrm{ha}^{-1}$ in 2014) as green manure after rice straw incorporation. The plant grown in the plot (green manure and weeds) were cut and incorporated into the soil on next early summer in all treatment.

Table 1. Field management practice.

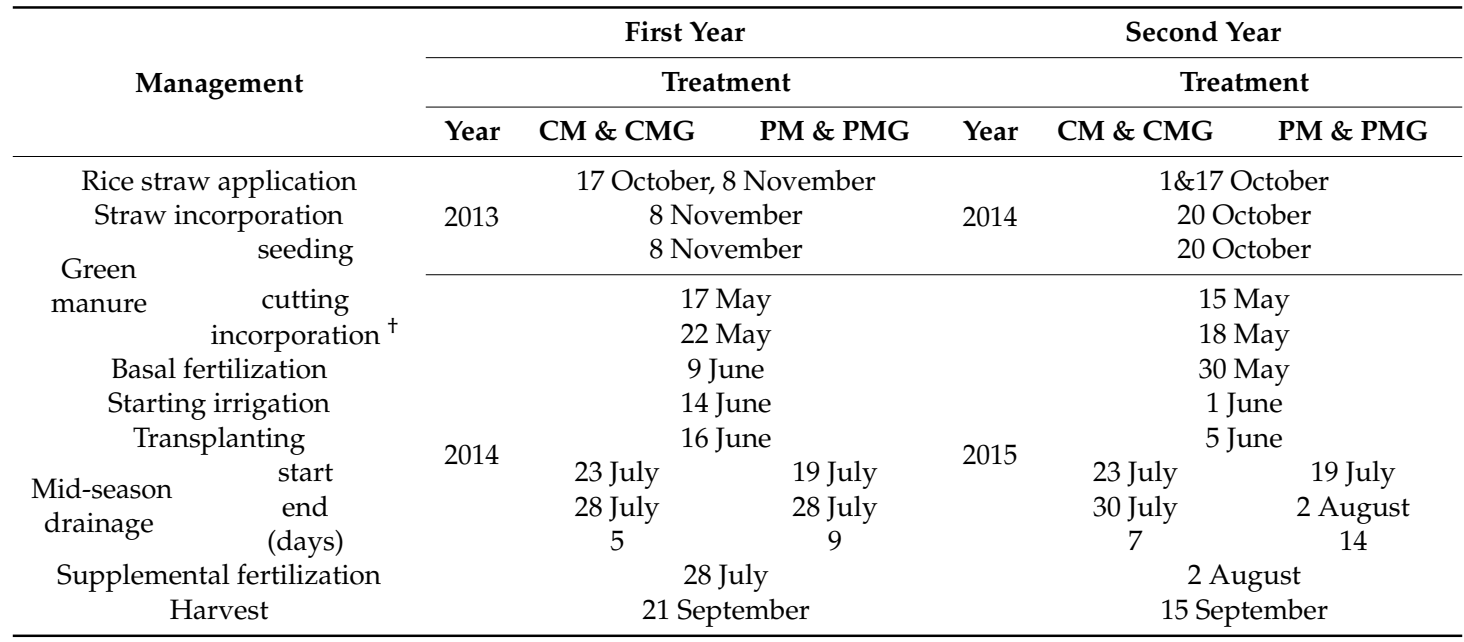

CM: conventional mid-season drainage, CMG: conventional mid-season drainage with green manure application, PM: prolonged mid-season drainage, PMG: prolonged mid-season drainage with green manure application. + : Only weeds were incorporated in CM and PM.

Basal fertilizer was applied to the $\mathrm{CM}$ and PM plots at the rate of $40 \mathrm{~kg} \mathrm{ha}^{-1}$ ammonium-nitrogen, $17.5 \mathrm{~kg} \mathrm{ha}^{-1}$ phosphorus ( $\mathrm{P}$, in the form of $40 \mathrm{~kg} \mathrm{P}_{2} \mathrm{O}_{5} \mathrm{ha}^{-1}$ ), and $24.9 \mathrm{~kg} \mathrm{ha}^{-1}$ potassium $(\mathrm{K}$, in the form of $60 \mathrm{~kg} \mathrm{~K}_{2} \mathrm{O} \mathrm{ha}{ }^{-1}$ ). In the CMG and PMG plots, urea was applied in both years as a basal fertilizer supplying $10 \mathrm{~kg} \mathrm{ha}^{-1}$ of nitrogen. Supplemental fertilizers $\left(40 \mathrm{~kg} \mathrm{~N} \mathrm{ha}^{-1}, 12 \mathrm{~kg} \mathrm{~K} \mathrm{ha}^{-1}\right)$ were applied to the all treatments after finishing mid-season drainage. Rice seedlings (c.v. Akitakomachi) were transplanted at the rate of 15.2 hills $\mathrm{m}^{-2}$.

Plots were irrigated appropriately. In the early growth stages of rice plants, the paddy field was kept flooded until mid-season drainage. Paddy water was drained through irrigation ditches during mid-season drainage. In the PM and PMG plots, mid-season drainage was carried out for 9 and 14 days in the first and second year. In the CM and CMG plots, it was carried out for 5 and 7 days in the first and second year. Because the weather in July 2014 was hot and dry, mid-season drainage ended on the same day in all treatments to avoid serious drought in the PM and PMG plots. 


\subsection{Gas Flux Measurements}

GHG fluxes were measured with the closed chamber technique. In the fallow season, gas flux was measured using stainless-steel bases and chambers, as described by Toma et al. [7]. Two stainless-steel bases were installed per plot to measure $\mathrm{CH}_{4}$ and $\mathrm{N}_{2} \mathrm{O}$ fluxes from green manure-covered soil, and $\mathrm{CO}_{2}$ flux from bare soil surfaces. To prevent plant growth on soil surfaces intended for $\mathrm{CO}_{2}$ flux measurement, herbicide was applied around the stainless-steel bases at least 1 week before $\mathrm{CO}_{2}$ flux measurement. During the growing season, acrylic chambers divided into upper and lower compartments were used for measuring $\mathrm{CH}_{4}$ and $\mathrm{N}_{2} \mathrm{O}$ fluxes [6,7]. For measuring $\mathrm{CO}_{2}$ flux, stainless-steel bases were installed between rows. PVC collars $(20 \mathrm{~cm}$ high) were positioned under the stainless-steel bases to deter root growth under the base area, consequently preventing $\mathrm{CO}_{2}$ contamination from roots [19].

$\mathrm{CH}_{4}$ and $\mathrm{N}_{2} \mathrm{O}$ gas samples were collected in vacuum-sealed vials fitted with butyl rubber stoppers, at 0,30 , and $60 \mathrm{~min}$ in the fallow season and at 4, 14, and $24 \mathrm{~min}$ in the growing season after the chambers were deployed. Gas samples for $\mathrm{CO}_{2}$ flux measurement were collected at 0, 6, and $12 \mathrm{~min}$ using Tedlar ${ }^{\circledR}$ bags $(500 \mathrm{~mL}) . \mathrm{CH}_{4}$ and $\mathrm{N}_{2} \mathrm{O}$ concentrations were analyzed with a gas chromatography (GC) fitted with a flame-ionization detector (GC-8A, Shimadzu, Kyoto, Japan) and an electron-capture detector (GC-14B, Shimadzu, Kyoto, Japan), respectively. $\mathrm{CO}_{2}$ concentrations were analyzed with a $\mathrm{CO}_{2}$ analyzer (ZFP-9, Fuji Electric Systems, Tokyo, Japan). Gas fluxes were measured every 2 weeks during fallow seasons and early and late growing seasons. During mid-season drainage and after plant biomass incorporation, gas samples were collected every 2 days.

In this study, $\mathrm{CO}_{2}$ emissions from bare soil surfaces in the fallow season and between rows in the rice growing season were defined as soil organic carbon decomposition or heterotrophic respiration (Rh) [6]. $\mathrm{Rh}, \mathrm{CH}_{4}$, and $\mathrm{N}_{2} \mathrm{O}$ fluxes were calculated by linear regression. There were significant correlations between $\mathrm{Rh}$ and soil temperature (at a depth of $5 \mathrm{~cm}$ ) during the fallow season as described in Results (Table S1). Therefore, Rh in the fallow season was estimated using hourly soil temperature measured in the presence of plants (GM and weeds) and the correlation between soil temperature measured in bare soil and $\mathrm{Rh}$ [20]. Integrated values of $\mathrm{Rh}, \mathrm{CH}_{4}$, and $\mathrm{N}_{2} \mathrm{O}$ were determined by the trapezoidal method according to Toma et al. [7]. Cumulative $\mathrm{CH}_{4}, \mathrm{~N}_{2} \mathrm{O}$, and $\mathrm{Rh}$ emissions were calculated periodically and annually (Table 2).

Table 2. Accumulation period of methane and nitrous oxide emissions and heterotrophic respiration.

\begin{tabular}{|c|c|c|c|c|c|c|}
\hline \multirow[b]{2}{*}{ Year } & \multirow[b]{2}{*}{ Treatment } & \multirow[b]{2}{*}{ Annual } & \multirow[b]{2}{*}{ Fallow Season } & \multicolumn{3}{|c|}{ Rice Growing Season } \\
\hline & & & & Early Growing & $\begin{array}{l}\text { Midseason } \\
\text { Drainage }\end{array}$ & Late Growing \\
\hline 2013-2014 & $\begin{array}{l}\text { PM } \\
\text { PMG }\end{array}$ & $\begin{array}{l}27 \text { October-21 September } \\
\text { (329 days) }\end{array}$ & $\begin{array}{l}27 \text { October-17 June } \\
\text { (233 days) }\end{array}$ & $\begin{array}{l}17 \text { June-19 July } \\
\text { (32 days) }\end{array}$ & $\begin{array}{l}\text { 19-28 July } \\
\text { (9 days) }\end{array}$ & $\begin{array}{c}28 \text { July-21 September } \\
\text { (55 days) }\end{array}$ \\
\hline 2014-2015 & $\begin{array}{c}\text { PM } \\
\text { PMG }\end{array}$ & $\begin{array}{l}16 \text { October-15 September } \\
\text { (334 days) }\end{array}$ & $\begin{array}{l}16 \text { October-7 June } \\
\text { (234 days) }\end{array}$ & $\begin{array}{l}7 \text { June-19 July } \\
\text { (42 days) }\end{array}$ & $\begin{array}{l}19 \text { July-2 August } \\
\text { (14 days) }\end{array}$ & $\begin{array}{c}2 \text { August-15 September } \\
\text { (44 days) }\end{array}$ \\
\hline
\end{tabular}

CM: conventional mid-season drainage, CMG: conventional mid-season drainage with green manure application, PM: prolonged mid-season drainage, PMG: prolonged mid-season drainage with green manure application.

\subsection{Amount of Carbon Applied in the Form of Rice Straw, Green Manure, and Other Plants}

The amount of carbon applied as rice straw was determined from rice straw mass and its carbon concentration measured with an NC analyzer (Sumigraph NC-80, Sumika, Osaka, Japan). A week before cutting the green manure, all aboveground biomass was collected from a $0.25 \mathrm{~m}^{2}(50 \mathrm{~cm} \times 50 \mathrm{~cm})$ area in all treatments. The belowground biomass was collected from a $0.06 \mathrm{~m}^{-2}(25 \mathrm{~cm} \times 25 \mathrm{~cm})$ area in the aboveground biomass collection area. Aboveground biomass was separated into green manure and weeds. Belowground biomass was washed with tap water to remove soil. All plant material 
was dried at $70{ }^{\circ} \mathrm{C}$ and powdered. Concentrations of carbon and nitrogen were measured using the NC analyzer.

\subsection{Calculating Net Greenhouse Gas Emissions}

The GWPs, including climate-carbon feedbacks, of $\mathrm{CH}_{4}$ and $\mathrm{N}_{2} \mathrm{O}$ were 34 and 298 times higher, respectively, than the GWP of $\mathrm{CO}_{2}$ over 100-year time horizon [21]. The NGHGE was calculated as the sum of the GWP values of all GHG, carbon inputs, and carbon outputs:

$$
\text { NGHGE }\left(\mathrm{Mg} \mathrm{CO}_{2} \mathrm{eq} \mathrm{ha}^{-1} \text { year }^{-1}\right)=\mathrm{GWP}_{\mathrm{CH}_{4}}+\mathrm{GWP}_{\mathrm{N}_{2} \mathrm{O}}+\mathrm{GWP}_{\mathrm{Rh}}-\mathrm{GWP}_{\mathrm{RS}}-\mathrm{GWP}_{\mathrm{GM}} \text {, }
$$

where, $\mathrm{GWP}_{\mathrm{CH} 4}, \mathrm{GWP}_{\mathrm{N} 2 \mathrm{O}}, \mathrm{GWP}_{\mathrm{Rh}}, \mathrm{GWP}_{\mathrm{RS}}$, and $\mathrm{GWP}_{\mathrm{GM}}$ were $\mathrm{GWP}$ of $\mathrm{CH}_{4}, \mathrm{~N}_{2} \mathrm{O}$, Rh, rice straw carbon, and green manure and weeds carbon, respectively. Each of GWP values $\left(\mathrm{Mg} \mathrm{CO}_{2} \mathrm{eq} \mathrm{ha}{ }^{-1}\right)$ were calculated as follows:

$$
\begin{gathered}
\mathrm{GWP}_{\mathrm{CH} 4}=\text { annual } \mathrm{CH}_{4} \text { emission }\left(\mathrm{Mg} \mathrm{Cha}^{-1} \text { year }^{-1}\right) \times 16 / 12 \times 34, \\
\mathrm{GWP}_{\mathrm{N} 2 \mathrm{O}}=\operatorname{annual} \mathrm{N}_{2} \mathrm{O} \text { emission }\left(\mathrm{Mg} \mathrm{N} \mathrm{ha}^{-1} \text { year }^{-1}\right) \times 44 / 28 \times 298, \\
\mathrm{GWP}_{\mathrm{Rh}}=\mathrm{Rh}\left(\mathrm{Mg} \mathrm{C} \mathrm{ha}{ }^{-1} \text { year }^{-1}\right) \times 44 / 12, \\
\mathrm{GWP}_{\mathrm{RS}}=\mathrm{C} \text { application rate of rice straw }\left(\mathrm{Mg} \mathrm{C}^{-1} \text { year }^{-1}\right) \times 44 / 12, \\
\mathrm{GWP}_{\mathrm{GM}}=\text { application rate of aboveground- and belowground biomass C } \\
\text { of GM and weeds }\left(\mathrm{Mg} \mathrm{C} \mathrm{ha}^{-1} \text { year }^{-1}\right) \times 44 / 12,
\end{gathered}
$$

\subsection{Ancillary Measurements}

Soil samples were collected from a depth of $0-10 \mathrm{~cm}$ when gas fluxes were measured and extracted with $2 \mathrm{M} \mathrm{KCl}$ for measuring ammonium-nitrogen $\left(\mathrm{NH}_{4}{ }^{+}\right)$and nitrate-nitrogen $\left(\mathrm{NO}_{3}{ }^{-}\right)$concentrations by indophenol blue and vanadium (III) chloride-nitrogen-ethylenediamine dihydrochloride colorimetry, respectively. Soil water content of the soil samples was also measured. Soil samples for the measurement of $\mathrm{Fe}^{2+}$ concentrations were collected from a depth of $0-10 \mathrm{~cm}$ five or six times during the rice growing period and extracted with $1 \mathrm{M}$ sodium acetate at $\mathrm{pH}$ 3.0. The $\mathrm{Fe}^{2+}$ concentrations of the extracts were analyzed by $0.2 \%$ o-phenanthroline colorimetry. Soil redox potential (Eh) was measured at a depth of $5 \mathrm{~cm}$ with three replicates per plot. Soil temperatures at 5 -cm depth were measured continuously by thermistors (Ondotori Jr. RTR 502, T\&D, Nagano, Japan). Air temperature and precipitation were measured at the weather station on the Ehime University Farm.

Eight rice plants per plot were clipped and dried at harvest time. Panicles were counted and rice sheaves were dried for 1 week. Grains were separated from the straw, their husks removed, and 1000 brown rice grains were weighed using a grain inspector (RGQI10A, Satake, Hiroshima, Japan). The brown rice yield per unit area was calculated from plant density and brown rice yield per plant.

\subsection{Statistical Analyses}

All statistical analyses were performed using ' $R$ ' software (version 3.1.0) [22]. Statistically significant differences in cumulative GHG emissions, daily GHG fluxes, and NGHGE between treatments were determined periodically and annually using the Tukey's test following one-way analysis of variance (ANOVA). The effects of prolongation of mid-season drainage, green manure and weed application, and their interaction were evaluated by two-way ANOVA in the first and second years. Over the entire study period, the effects of three factors (mid-season drainage prolongation, green manure and weed application, year, and their interaction) on GHG emissions, daily GHG fluxes, and NGHGE were analyzed by three-way ANOVA. Correlations between GHG emissions, NGHGE and applied carbon of rice straw, green manure, and weed biomass were investigated using the Pearson's rank correlation coefficient test. Statistically significant differences are reported at $P<0.05$ level. 


\section{Results}

The $\mathrm{CH}_{4}$ flux in the fallow season was lower than $0.2 \mathrm{mg} \mathrm{C} \mathrm{m}^{-2} \mathrm{hr}^{-1}$ (Figure S1). In the growing season, $\mathrm{CH}_{4}$ flux increased, especially in the early part of the season, in all treatments (Figure 1a,d). After mid-season drainage, $\mathrm{CH}_{4}$ flux was low towards the end of the growing season. In the first year, $\mathrm{CH}_{4}$ flux decreased and Eh increased faster in PM and PMG than in CM and CMG (Figure 1a,c). In the second year, $\mathrm{CH}_{4}$ flux in all treatment increased just after the starting MD (Figure 1d,f). The variation between treatments in soil water content was greater in the early growing season, decreased during mid-season drainage, and increased after that (Figure 1e,a).

Seasonal $\mathrm{N}_{2} \mathrm{O}$ flux variations are shown in Figure 2a,d. During the fallow season, $\mathrm{N}_{2} \mathrm{O}$ fluxes across treatments were approximately $0 \mu \mathrm{g} \mathrm{N} \mathrm{m}^{-2} \mathrm{hr}^{-1}$ in both years. However, they increased sharply and peaked (at 130 and $52.5 \mu \mathrm{g} \mathrm{N} \mathrm{m}{ }^{-2} \mathrm{hr}^{-1}$ in the first and the second years, respectively) after green manure and weeds incorporation (Figure $2 \mathrm{a}, \mathrm{d}$ ). The lowest $\mathrm{N}_{2} \mathrm{O}$ fluxes were observed during the mid-season drainage in the first year $\left(-79.7 \mu \mathrm{g} \mathrm{N} \mathrm{m} \mathrm{hr}^{-1}\right.$; Figure 2a) and in the late growing season in the second year (-35.8 $\mu \mathrm{g} \mathrm{N} \mathrm{m}^{-2} \mathrm{hr}^{-1}$; Figure 2d).

Seasonal Rh variations are shown in Figure $3 \mathrm{a}, \mathrm{b}$. In the fallow season, $\mathrm{Rh}$ in all treatments decreased from autumn to winter and increased towards spring. There were significant correlations between Rh and soil temperature in the fallow season in all treatments in both years, except for two plots in treatments CMG and PMG in the first and second years, respectively (Table S1). Rh increased in the early growing season and during mid-season drainage in both years (Figure 3). After mid-season drainage, Rh decreased in the late growing season in all treatments in the first year, whereas it decreased only in CM and CMG in the second year.

Annual $\mathrm{CH}_{4}$ emissions were not significantly different between treatments in the first and second years (Figure $4 \mathrm{a}, \mathrm{b}$ ). The cumulative $\mathrm{CH}_{4}$ emissions in the growing season accounted for nearly $100 \%$ of the annual $\mathrm{CH}_{4}$ emission in the first and second years, and cumulative $\mathrm{CH}_{4}$ emission in the early growing season contributed to more than $70 \%$ of the emission in the growing season (Table S2). The averages of annual $\mathrm{CH}_{4}$ emission in PM and PMG $\left(363 \mathrm{~kg} \mathrm{C} \mathrm{ha}^{-1}\right.$ in the first year, $998 \mathrm{~kg} \mathrm{C} \mathrm{ha}^{-1}$ in the second year) were $69.8 \%$ and $93.3 \%$ of that in CM and CMG $\left(520 \mathrm{~kg} \mathrm{C} \mathrm{ha}^{-1}\right.$ in the first year, $1070 \mathrm{~kg} \mathrm{C} \mathrm{ha}^{-1}$ in the second year) in the first and second years, respectively. In the second year, cumulative $\mathrm{CH}_{4}$ emissions during the mid-season drainage were significantly higher in $\mathrm{PM}$ $\left(169 \mathrm{~kg} \mathrm{Cha}^{-1}\right)$ and PMG $\left(144 \mathrm{~kg} \mathrm{C} \mathrm{ha}^{-1}\right)$ than those in CM $\left(45.4 \mathrm{~kg} \mathrm{Cha}^{-1}\right)$ and CMG $\left(47.5 \mathrm{~kg} \mathrm{C} \mathrm{ha}^{-1}\right)$; and 2-year average of cumulative $\mathrm{CH}_{4}$ emission was significantly higher in $\mathrm{PM}\left(116 \mathrm{~kg} \mathrm{Cha}^{-1}\right)$ than in CM (43.2 $\mathrm{kg} \mathrm{C} \mathrm{ha}^{-1}$; Table S2).

There were no significant differences in annual $\mathrm{N}_{2} \mathrm{O}$ emission between treatments in the first and second years (Figure $4 c, d$ ). Cumulative $\mathrm{N}_{2} \mathrm{O}$ emissions in the fallow season were higher than those in the growing season, and they contributed approximately $55-156 \%$ to the annual $\mathrm{N}_{2} \mathrm{O}$ emissions (Table S4). In the first year, cumulative $\mathrm{N}_{2} \mathrm{O}$ emission and daily $\mathrm{N}_{2} \mathrm{O}$ flux in the late growing season and the entire growing season were lower in PMG than those in CMG and PM (Tables S4 and S5). In the second year, cumulative $\mathrm{N}_{2} \mathrm{O}$ emission in PMG $\left(0.34 \mathrm{~kg} \mathrm{~N} \mathrm{ha}^{-1}\right)$ was significantly higher than that in CMG $\left(0.12 \mathrm{~kg} \mathrm{~N} \mathrm{ha}^{-1}\right)$ and PM $\left(0.11 \mathrm{~kg} \mathrm{~N} \mathrm{ha}^{-1}\right)$ in the fallow season (Table S4).

There were no significant differences in the annual Rh between the treatments in the first and second years (Figure $4 \mathrm{e}, \mathrm{f}$ ). The cumulative $\mathrm{Rh}$ in the fallow season contributed approximately $55.2 \%$ to the annual $\mathrm{Rh}$ in all treatment (Table S6). During mid-season drainage, cumulative Rh values were significantly higher in PM $\left(0.53 \mathrm{MgC} \mathrm{ha}^{-1}\right.$ in the first year, $0.47 \mathrm{MgC} \mathrm{ha}^{-1}$ in the second year) and PMG (0.46 Mg C ha ${ }^{-1}$ in the first year, $0.47 \mathrm{Mg} \mathrm{C} \mathrm{ha}^{-1}$ in the second year) than those in CM $\left(0.25 \mathrm{Mg} \mathrm{C} \mathrm{ha}^{-1}\right.$ in the first year, $0.24 \mathrm{MgC} \mathrm{ha}^{-1}$ in the second year) and CMG $\left(0.22 \mathrm{Mg} \mathrm{Cha}^{-1}\right.$ in the first year, $0.24 \mathrm{MgC} \mathrm{ha}^{-1}$ in the second year) (Table S6), whereas daily Rh during mid-season drainage was not significantly different between treatments (Table S7). 

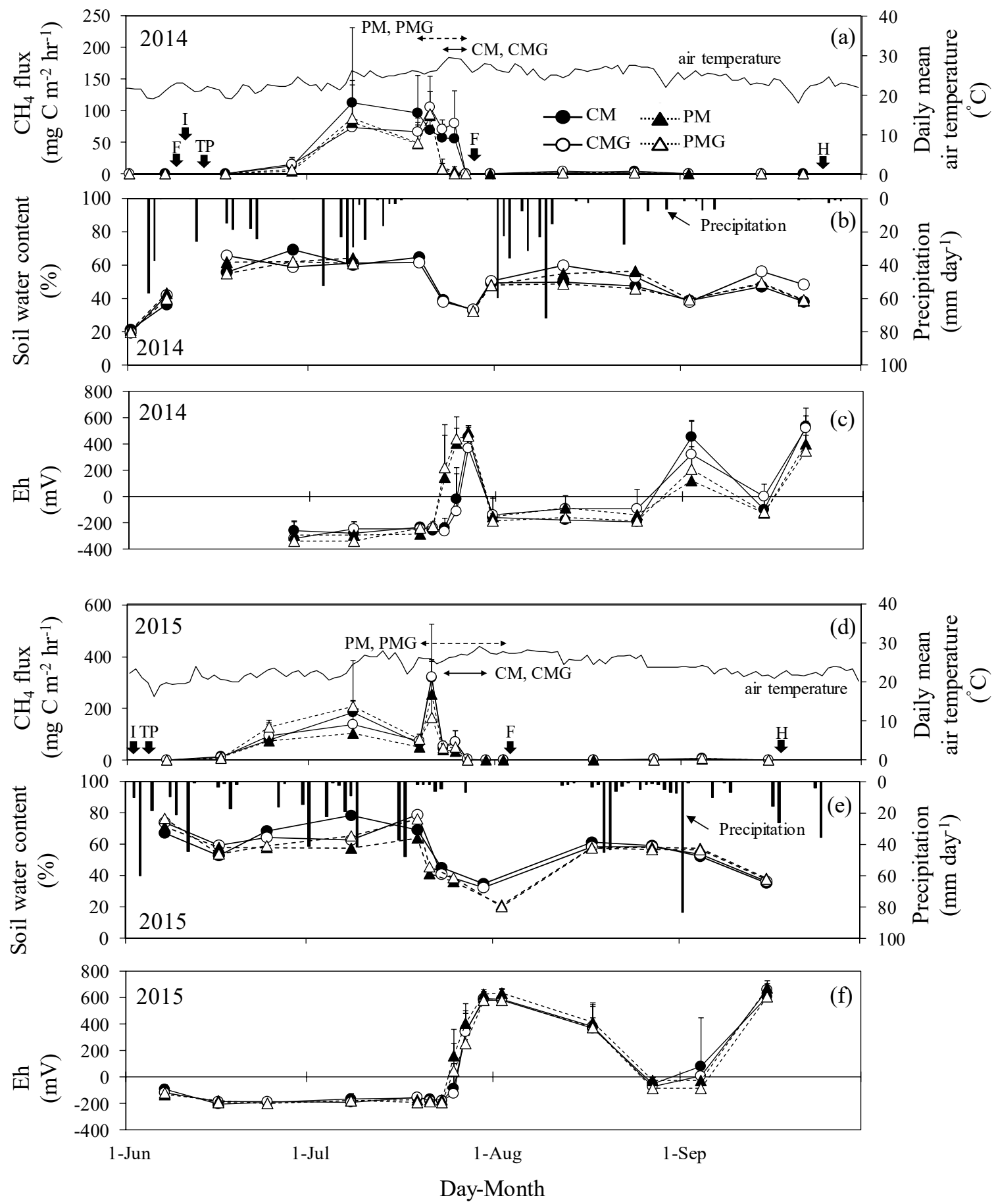

Figure 1. Seasonal variations in daily mean air temperature and $\mathrm{CH}_{4}$ flux $(\mathbf{a}, \mathbf{d})$, precipitation and soil water content $(\mathbf{b}, \mathbf{e})$, and Eh $(\mathbf{c}, \mathbf{f})$ during the growing season. Error bars represent standard deviations. I, F, TP, and $\mathrm{H}$ represent irrigation, fertilization, transplanting, and harvest, respectively. Arrows of the continuous and dotted lines show the periods of mid-season drainage. 


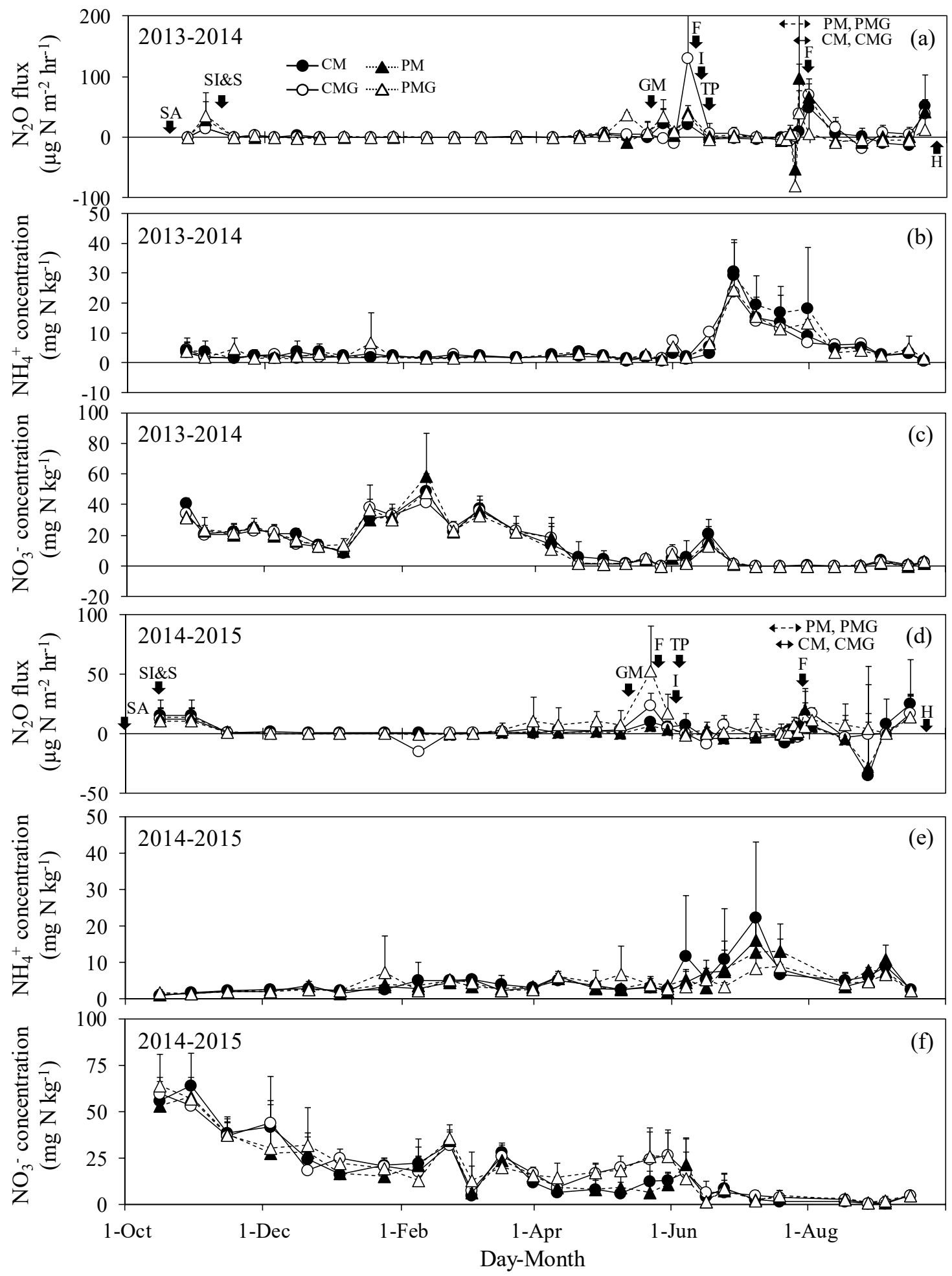

Figure 2. Seasonal variations in $\mathrm{N}_{2} \mathrm{O}$ flux $(\mathbf{a}, \mathbf{d})$, ammonium $\left(\mathrm{NH}_{4}{ }^{+}\right)$concentration $(\mathbf{b}, \mathbf{e})$, and nitrate $\left(\mathrm{NO}_{3}{ }^{-}\right)$concentration $(\mathbf{c}, \mathbf{f})$. Error bars represent standard deviations. SA, SI, and S represent straw application, incorporation, and seeding, respectively. GM, I, F, TP, and $\mathrm{H}$ represent green manure and weeds incorporations, irrigation, fertilization, transplanting, and harvest, respectively. Arrows of the continuous and dotted lines show the periods of mid-season drainage. 

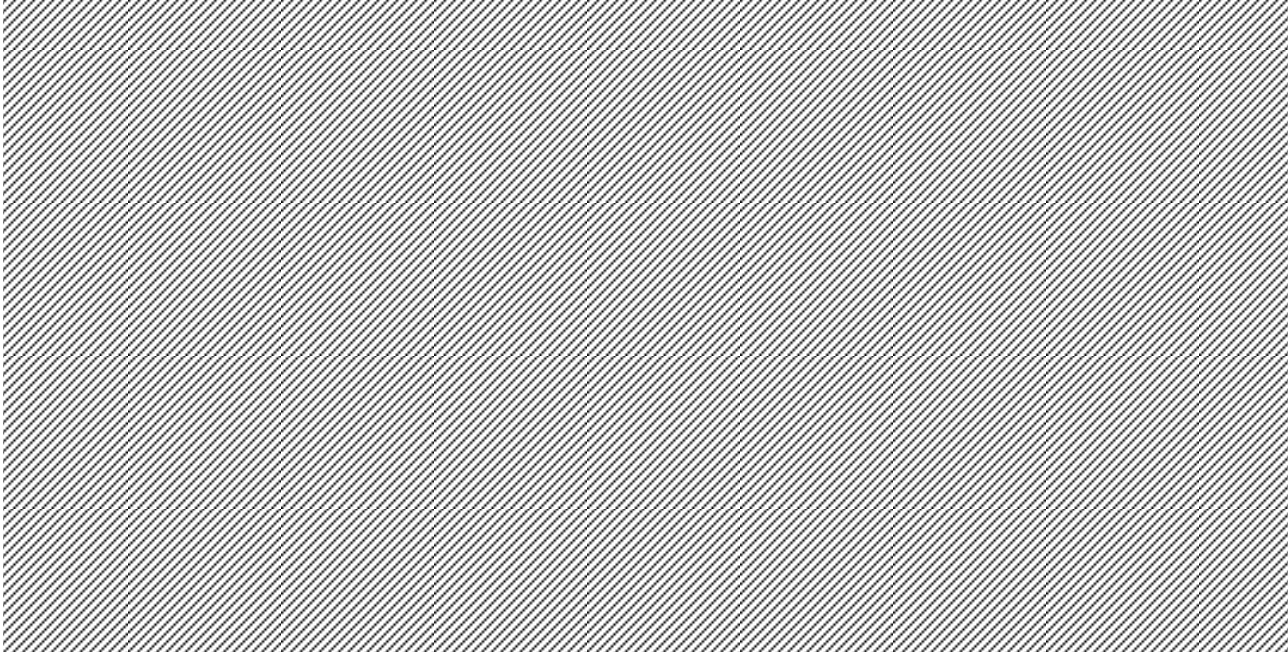

Figure 3. Seasonal variations in heterotrophic respiration (Rh) in the first (a) and second (b) years Error bars represent standard deviations. SA, SI, and S represent straw application, incorporation, and seeding, respectively. GM, I, F, TP, and H represent green manure and weeds incorporations, irrigation, fertilization, transplanting, and harvest, respectively. Arrows of the continuous and dotted lines show the periods of mid-season drainage.

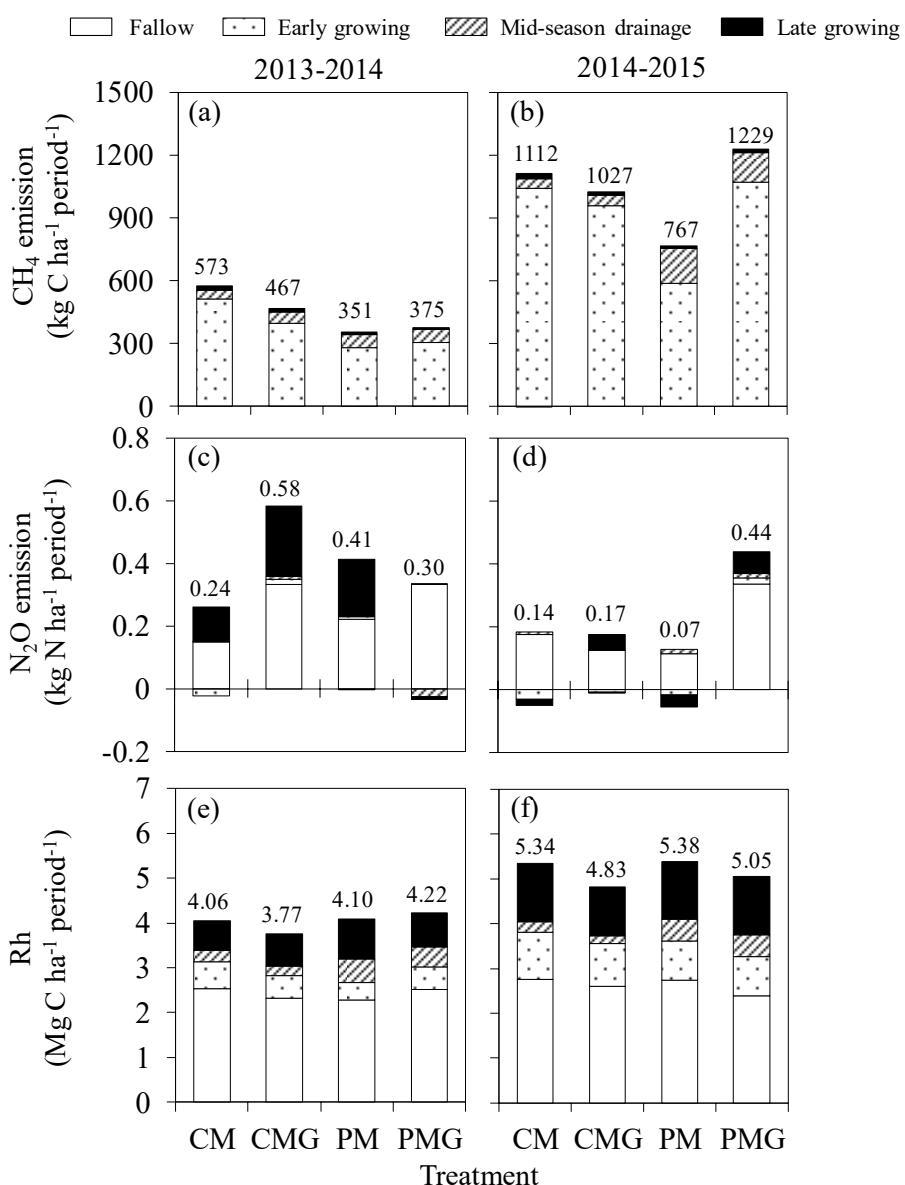

Figure 4. Cumulative $\mathrm{CH}_{4}(\mathbf{a}, \mathbf{b})$ and $\mathrm{N}_{2} \mathrm{O}(\mathbf{c}, \mathbf{d})$ emissions and heterotrophic respirations (Rh) (e,f). Number in the figures represent annual emission of $\mathrm{CH}_{4}, \mathrm{~N}_{2} \mathrm{O}$, and $\mathrm{Rh}$. Left and right figures represent the data collected in the first (2013-2014) and the second (2014-2015) years, respectively. 
Over the study period, NGHGE did not differ significantly between treatments (Table 3). The 2-year average of $\mathrm{GWP}_{\mathrm{CH} 4}$ made the highest contribution to the 2-year average of NGHGE (by $93.6 \%$, $100 \%, 87.5 \%$, and $96.0 \%$ in CM, CMG, PM, and PMG, respectively) compared to other NGHGE component. Furthermore, the 2-year average of $\mathrm{GWP}_{\mathrm{Rh}}$ contributed by $42.1 \%, 45.4 \%, 59.8 \%$, and $44.8 \%$ in CM, CMG, PM, and PMG, respectively to the 2-year average of NGHGE. GWP ${ }_{\mathrm{GM}}, \mathrm{GWP}_{\mathrm{Rh}}, \mathrm{GWP}_{\mathrm{CH} 4}$, and NGHGE were significantly affected by treatment year. $\mathrm{GWP}_{\mathrm{GM}}$ was significantly affected by green manure and weeds applications and $\mathrm{GWP}_{\mathrm{N} 2 \mathrm{O}}$ was significantly affected by the tree-way interaction between mid-season drainage prolongation, green manure and weeds applications, and year.

Table 3. Net greenhouse gas emission (NGHGE) (Mean \pm SD).

\begin{tabular}{|c|c|c|c|c|c|c|c|c|}
\hline \multirow{2}{*}{ Year } & \multirow{2}{*}{\multicolumn{2}{|c|}{ Treatment }} & $\mathrm{GWP}_{\mathrm{RS}}$ & $\mathrm{GWP}_{\mathrm{GM}}$ & $\mathrm{GWP}_{\mathrm{Rh}}$ & $\mathrm{GWP}_{\mathrm{CH} 4}$ & $\mathrm{GWP}_{\mathrm{N} 2 \mathrm{O}}$ & NGHGE \\
\hline & & & \multicolumn{6}{|c|}{$\left(\mathrm{MgCO}_{2}\right.$ eq ha ${ }^{-1}$ year $\left.^{-1}\right)$} \\
\hline \multirow{7}{*}{ 2013-2014 } & & $\mathrm{CM}$ & \multirow{4}{*}{-8.47} & -7.57 & 14.9 & 26.0 & 0.11 & $24.9 \pm 16.9$ \\
\hline & & CMG & & -8.36 & 13.8 & 21.2 & 0.27 & $18.4 \pm 8.14$ \\
\hline & & PM & & -6.17 & 15.0 & 15.9 & 0.19 & $16.5 \pm 12.0$ \\
\hline & & PMG & & -8.47 & 15.5 & 17.0 & 0.14 & $15.7 \pm 7.09$ \\
\hline & \multirow{3}{*}{$P$} & MD & \multirow{3}{*}{ na } & 0.36 & 0.40 & 0.22 & 0.67 & 0.36 \\
\hline & & GM & & $<0.05$ & 0.77 & 0.74 & 0.39 & 0.54 \\
\hline & & $\mathrm{MD} \times \mathrm{GM}$ & & 0.29 & 0.48 & 0.60 & 0.10 & 0.64 \\
\hline \multirow{7}{*}{ 2014-2015 } & & $\mathrm{CM}$ & \multirow{4}{*}{-4.12} & -9.22 & 19.6 & 50.4 & 0.06 & $56.7 \pm 13.7$ \\
\hline & & $\mathrm{CMG}$ & & -10.6 & 17.7 & 46.6 & 0.08 & $49.6 \pm 8.80$ \\
\hline & & PM & & -9.05 & 19.7 & 34.8 & 0.03 & $41.4 \pm 12.1$ \\
\hline & & PMG & & -10.4 & 18.5 & 55.7 & 0.21 & $59.9 \pm 22.4$ \\
\hline & \multirow{3}{*}{$P$} & MD & \multirow{3}{*}{ na } & 0.86 & 0.79 & 0.67 & 0.43 & 0.77 \\
\hline & & GM & & 0.10 & 0.41 & 0.27 & 0.13 & 0.46 \\
\hline & & $\mathrm{MD} \times \mathrm{GM}$ & & 0.96 & 0.85 & 0.12 & 0.21 & 0.12 \\
\hline \multirow{11}{*}{ 2013-2015 } & & $\mathrm{CM}$ & \multirow{4}{*}{-6.30} & -8.40 & 17.2 & 38.2 & 0.09 & $40.8 \pm 14.0$ \\
\hline & & $\mathrm{CMG}$ & & -9.45 & 15.8 & 33.9 & 0.18 & $34.0 \pm 4.22$ \\
\hline & & PM & & -7.61 & 17.4 & 25.3 & 0.11 & $28.9 \pm 9.02$ \\
\hline & & PMG & & -9.46 & 17.0 & 36.3 & 0.17 & $37.8 \pm 11.1$ \\
\hline & \multirow{7}{*}{$P$} & MD & \multirow{7}{*}{ na } & 0.45 & 0.51 & 0.27 & 0.80 & 0.40 \\
\hline & & GM & & $<0.01$ & 0.38 & 0.47 & 0.09 & 0.83 \\
\hline & & Year & & $<0.01$ & $<0.001$ & $<0.01$ & 0.06 & $<0.001$ \\
\hline & & $\mathrm{MD} \times \mathrm{GM}$ & & 0.45 & 0.60 & 0.11 & 0.72 & 0.12 \\
\hline & & $\mathrm{MD} \times$ Year & & 0.66 & 0.84 & 0.68 & 0.39 & 0.75 \\
\hline & & $\mathrm{GM} \times$ Year & & 0.86 & 0.56 & 0.27 & 0.63 & 0.34 \\
\hline & & $\begin{array}{c}\mathrm{MD} \times \mathrm{GM} \times \\
\text { Year }\end{array}$ & & 0.49 & 0.85 & 0.31 & $<0.05$ & 0.31 \\
\hline
\end{tabular}

$\mathrm{GWP}_{\mathrm{RS}}, \mathrm{GWP}_{\mathrm{GM}}, \mathrm{GWP}_{\mathrm{Rh}}, \mathrm{GWP}_{\mathrm{CH} 4}$, and $\mathrm{GWP}_{\mathrm{N} 2 \mathrm{O}}$ represent carbon dioxide equivalent values of applied carbon in rice straw, green manure and weeds, $\mathrm{Rh}, \mathrm{CH}_{4}$ emission, and $\mathrm{N}_{2} \mathrm{O}$ emission, respectively. $\mathrm{CM}$ : conventional mid-season drainage, CMG: conventional mid-season drainage with green manure application, PM: prolonged mid-season drainage, PMG: prolonged mid-season drainage with green manure application. $P$ values represent the results of two- or thee way ANOVA between mid-season drainage (MD) prolongation, green manure (GM) application, and year. Bold values represent statistically significant.

Linear positive correlations between $\mathrm{N}_{2} \mathrm{O}$ flux and $\mathrm{Rh}$ in the fallow season were observed in $\mathrm{CM}$ $\left(\mathrm{y}=0.08 \mathrm{x}-1.61, R^{2}=0.46, P<0.05\right), \mathrm{PM}\left(\mathrm{y}=0.13 \mathrm{x}-3.61, R^{2}=0.49, P<0.01\right)$, and PGM $(\mathrm{y}=0.14 \mathrm{x}-$ $\left.2.80, R^{2}=0.72, P<0.01\right)$ in the first year (Figure 5a) and in CM $\left(\mathrm{y}=0.06 \mathrm{x}-1.17, R^{2}=0.62, P<0.01\right.$ ), CMG $\left(\mathrm{y}=0.09 \mathrm{x}-2.20, R^{2}=0.70, P<0.001\right)$, PM $\left(\mathrm{y}=0.05 \mathrm{x}-0.88, R^{2}=0.48, P<0.001\right)$, and PMG $\left(\mathrm{y}=0.12 \mathrm{x}-1.60, R^{2}=0.84, P<0.001\right)$ in the second year (Figure $\left.5 \mathrm{~b}\right)$. There were strong relationships between GHG and applied carbon (with the highest correlation coefficients, Figure 6). Cumulative $\mathrm{CH}_{4}$ emission in the early growing season was positively correlated with applied biomass carbon in green manure and weeds (Figure 6a). Cumulative $\mathrm{N}_{2} \mathrm{O}$ emission in the late growing season was negatively correlated, and annual Rh was positively correlated with applied aboveground biomass carbon from weeds (Figure 6b,c). NGHGE increased significantly with increasing applied biomass carbon from green manure and weeds $\left(\mathrm{y}=37.6 \mathrm{x}-54.1, R^{2}=0.64, P<0.05\right.$, data is not shown). There were no 
significant relationships between $\mathrm{N}_{2} \mathrm{O}$ emission and applied nitrogen (Table S9). Other correlation coefficients for the relationships between GHG emissions and inputs of carbon (from green manure, weeds, and roots) and nitrogen (from green manure, weeds, roots, and fertilized nitrogen) are given in Tables S8 and S9.
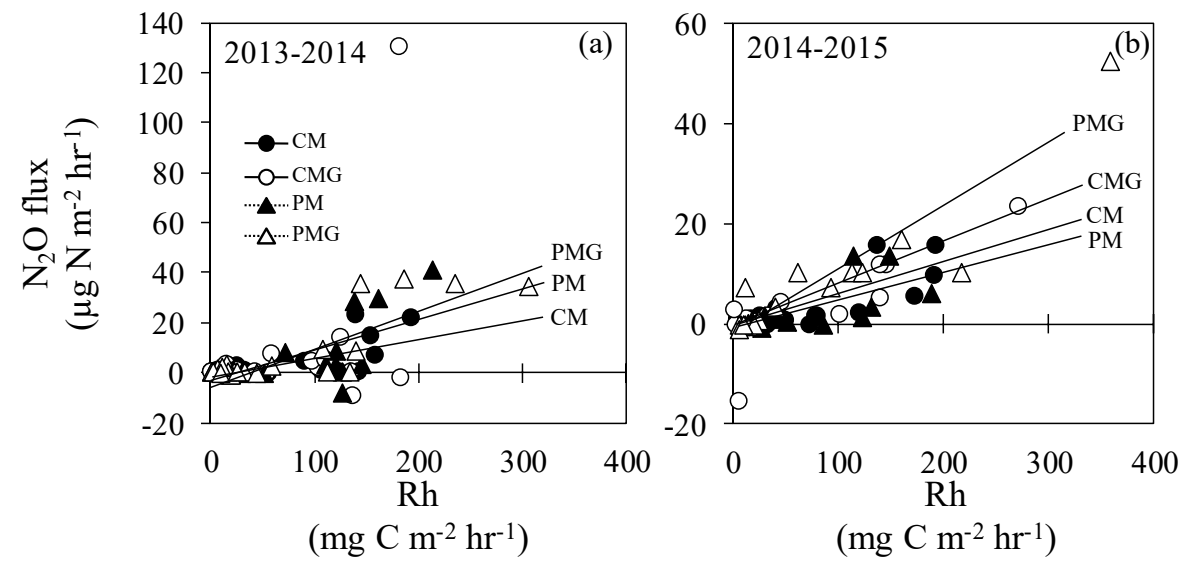

Figure 5. Relationship between heterotrophic respiration (Rh) and $\mathrm{N}_{2} \mathrm{O}$ flux in fallow season in the first (a) and second (b) years.

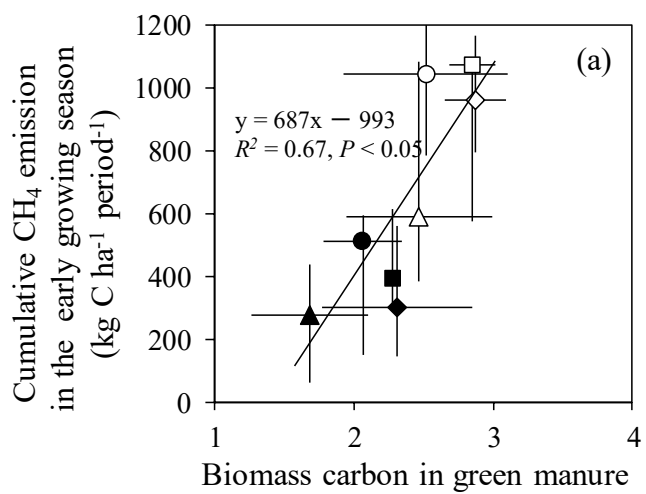

and weed

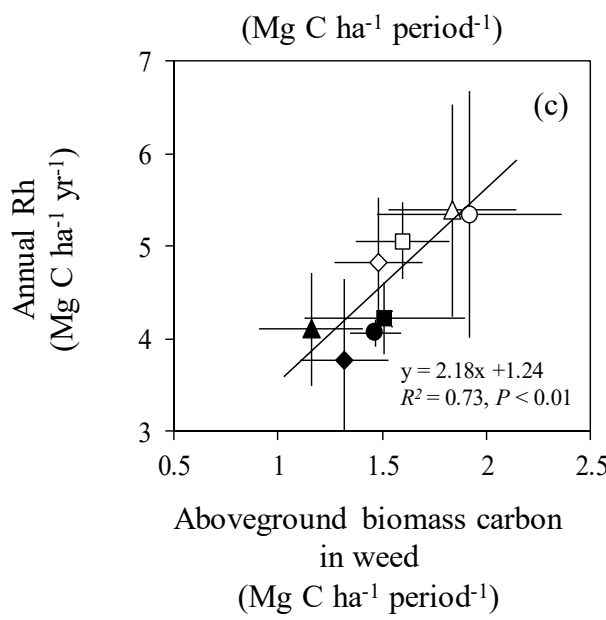

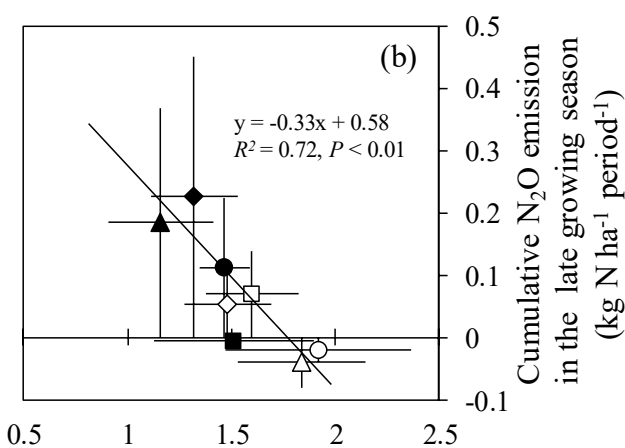

Aboveground biomass carbon in weed

$\left(\mathrm{Mg} \mathrm{C}^{-1}\right.$ period $\left.^{-1}\right)$

- $\mathrm{CM}$ in the first year

O $\mathrm{CM} n$ the second year

- $\mathrm{CMG}$ in the first year

$\square$ CMG $n$ the second year

$\Delta$ PM in the first year

$\triangle \mathrm{PM}$ in the second year

PMG in the first year

PMG $n$ the second year

Figure 6. Relationship between biomass carbon in green manure and weed and $\mathrm{CH}_{4}$ emission in early growing season (a), above-ground biomass carbon in weed and $\mathrm{N}_{2} \mathrm{O}$ emission in late growing season (b), and biomass carbon in green manure and weed and annual heterotrophic respiration (Rh) (c) in the first (2013-2014) and second (2014-2015) years. Error bars represent standard deviations.

Mean daily precipitation and mean air temperature during mid-season drainage was lower in the first year than in the second year (Table 4). After starting mid-season drainage in PM and PMG 
(4 days earlier than in CM and CMG in both years), there was no rainfall for 4 days in the first year, whereas $14 \mathrm{~mm}$ of rainfall was observed over 4 days in the second year. From March to May (after incorporation of green manure) in the first year, the mean daily soil temperature $\left(17.9^{\circ} \mathrm{C}\right)$ in $\mathrm{CM}$ and PM was slightly higher than that in CMG and PMG $\left(17.6^{\circ} \mathrm{C}\right)$. In the same time interval in the second year, the mean daily soil temperature in CMG and PMG $\left(16.9^{\circ} \mathrm{C}\right)$ was lower than that in $\mathrm{CM}$ and PM $\left(17.6{ }^{\circ} \mathrm{C}\right)$. The mean soil water content in CM and PM $(27.3 \%$ in the first year and $38.6 \%$ in the second year) was almost identical to that in CMG and PMG (27.5\% in the first year and $38.9 \%$ in the second year). $\mathrm{Fe}^{2+}$ concentrations at the end of mid-season drainage in $\mathrm{CM}\left(0.12\right.$ and $0.24 \mathrm{mg} \mathrm{Fe} \mathrm{kg}{ }^{-1}$ in the first and second years, respectively) and CMG (0.15 and $0.14 \mathrm{mg} \mathrm{Fe} \mathrm{kg}^{-1}$ in the first and second years, respectively) were higher than those in PM ( 0.03 and $0.03 \mathrm{mg} \mathrm{Fe} \mathrm{kg}^{-1}$ in the first and second years, respectively) and PMG (0.03 and $0.02 \mathrm{mg} \mathrm{Fe} \mathrm{kg}^{-1}$ in the first and second years, respectively) (Figure S2c and S3c). In the fallow season in both years, soil $\mathrm{NH}_{4}{ }^{+}$concentrations varied similarly in all treatments (Figure $2 \mathrm{~b}, \mathrm{e}$ ). Conversely, soil $\mathrm{NO}_{3}{ }^{-}$concentrations in the second year were slightly higher in CMG and PMG than those in CM and PM (Figure 2c,f).

Table 4. Mean air temperature and mean daily precipitation in each period.

\begin{tabular}{|c|c|c|c|c|c|c|}
\hline \multirow{2}{*}{ Year } & \multirow{2}{*}{ Treatment } & \multirow{2}{*}{ Annual } & \multirow{2}{*}{$\begin{array}{l}\text { Fallow } \\
\text { Season }\end{array}$} & \multicolumn{3}{|c|}{ Rice Growing Season } \\
\hline & & & & $\begin{array}{c}\text { Early } \\
\text { Growing }\end{array}$ & $\begin{array}{c}\text { Midseason } \\
\text { Drainage }\end{array}$ & $\begin{array}{c}\text { Late } \\
\text { Growing }\end{array}$ \\
\hline \multirow{4}{*}{ 2013-2014 } & $\mathrm{CM}$ & \multirow{4}{*}{$\begin{array}{c}15.8^{\circ} \mathrm{C} \\
4.37 \mathrm{~mm}\end{array}$} & \multirow{4}{*}{$\begin{array}{c}12.0^{\circ} \mathrm{C} \\
3.76 \mathrm{~mm}\end{array}$} & $23.5^{\circ} \mathrm{C}$ & $28.3^{\circ} \mathrm{C}$ & \multirow{4}{*}{$\begin{array}{c}24.8^{\circ} \mathrm{C} \\
5.35 \mathrm{~mm}\end{array}$} \\
\hline & CMG & & & $7.71 \mathrm{~mm}$ & $0.17 \mathrm{~mm}$ & \\
\hline & PM & & & $23.2^{\circ} \mathrm{C}$ & $27.3^{\circ} \mathrm{C}$ & \\
\hline & PMG & & & $8.67 \mathrm{~mm}$ & $0.10 \mathrm{~mm}$ & \\
\hline \multirow{4}{*}{ 2014-2015 } & $\mathrm{CM}$ & \multirow{4}{*}{$\begin{array}{c}16.1^{\circ} \mathrm{C} \\
4.49 \mathrm{~mm}\end{array}$} & \multirow{4}{*}{$\begin{array}{c}12.4^{\circ} \mathrm{C} \\
3.80 \mathrm{~mm}\end{array}$} & $22.7^{\circ} \mathrm{C}$ & $27.1^{\circ} \mathrm{C}$ & $24.4^{\circ} \mathrm{C}$ \\
\hline & CMG & & & $7.91 \mathrm{~mm}$ & $1.38 \mathrm{~mm}$ & $5.39 \mathrm{~mm}$ \\
\hline & PM & & & $22.5^{\circ} \mathrm{C}$ & $26.8^{\circ} \mathrm{C}$ & $24.2^{\circ} \mathrm{C}$ \\
\hline & PMG & & & $8.40 \mathrm{~mm}$ & $1.47 \mathrm{~mm}$ & $5.13 \mathrm{~mm}$ \\
\hline
\end{tabular}

CM: conventional mid-season drainage, CMG: conventional mid-season drainage with green manure application, PM: prolonged mid-season drainage, PMG: prolonged mid-season drainage with green manure application.

There were no significant differences in annually applied plant biomass carbon (3.59 to $4.62 \mathrm{Mg} \mathrm{C} \mathrm{ha}^{-1}$ year $^{-1}$ ) between the treatments (Table S10). Applied biomass carbon from green manure and weeds in the second year ( 2.47 to $2.88 \mathrm{Mg} \mathrm{C} \mathrm{ha}^{-1}$ ) was approximately $16 \%$ higher than that in the first year (1.68 to $2.31 \mathrm{Mg} \mathrm{C} \mathrm{ha}^{-1}$ ), whereas annually applied carbon in the second year (3.59 to $4.00 \mathrm{Mg} \mathrm{C} \mathrm{ha}^{-1}$ ) was approximately $13 \%$ lower than that in the first year (3.99 to $4.62 \mathrm{Mg} \mathrm{C} \mathrm{ha}^{-1}$ ). In CMG and PMG, the 2-year averages of applied plant biomass carbon ( $4.30 \mathrm{Mg} \mathrm{C} \mathrm{ha}^{-1}$ in both treatments) were $7.20 \%$ and $13.3 \%$ higher than those in $\mathrm{CM}\left(4.00 \mathrm{MgCha}^{-1}\right)$ and $\mathrm{PM}\left(3.79 \mathrm{MgC} \mathrm{ha}^{-1}\right)$, respectively. Applied plant biomass nitrogen was significantly higher in CMG (145 kg N ha ${ }^{-1}$ in the first year and $156 \mathrm{~kg} \mathrm{~N} \mathrm{ha}^{-1}$ in the second year) and PMG (149 $\mathrm{kg} \mathrm{N} \mathrm{ha}^{-1}$ in the first year and $148 \mathrm{~kg} \mathrm{~N} \mathrm{ha}^{-1}$ in the second year) than in $\mathrm{CM}\left(110 \mathrm{~kg} \mathrm{~N} \mathrm{ha}^{-1}\right.$ in the first year and $106 \mathrm{~kg} \mathrm{~N} \mathrm{ha}^{-1}$ in the second year) and PM (103 kg N ha ${ }^{-1}$ in the first year and $92.1 \mathrm{~kg} \mathrm{~N} \mathrm{ha}^{-1}$ in the second year) (Table S11). In contrast, annually applied nitrogen, which was the sum of plant biomass nitrogen and fertilized nitrogen, was not different between treatments (183 to $199 \mathrm{~kg} \mathrm{~N} \mathrm{ha}^{-1}$ in the first year, 172 to $206 \mathrm{~kg} \mathrm{~N} \mathrm{ha}^{-1}$ in the second year). There were no significant differences between the 2-year averages of brown rice yields in CM, CMG, PM, and PMG $\left(3.74,3.98,3.80\right.$, and $3.70 \mathrm{Mg}^{-1}$, respectively; Table S12). 


\section{Discussion}

\subsection{Methane Emission}

The high $\mathrm{CH}_{4}$ emission observed during the growing season of rice indicates that suppressing it during this period help to reduce annual $\mathrm{CH}_{4}$ emissions significantly. Furthermore, $\mathrm{CH}_{4}$ flux increased in the early growing season and decreased during mid-season drainage in this study and in previous studies involving other nearby sites [6,7]. In Japan, $\mathrm{CH}_{4}$ flux in paddy fields has been observed to peak mostly either early or late in the growing season or both (as two peaks, Itoh et al. [17]). Therefore, the best strategy for reducing $\mathrm{CH}_{4}$ emissions is to ensure emissions to be lower early in the growing season in areas where higher $\mathrm{CH}_{4}$ fluxes are observed during that period, such as the study field used in the current study.

Although organic matter application increases $\mathrm{CH}_{4}$ emission in paddy fields [12,13], a positive correlation between $\mathrm{CH}_{4}$ emission in the early growing season and biomass carbon from green manure and weeds suggests that the lack of effect of GM application on $\mathrm{CH}_{4}$ emission is because of the incorporation of weeds and belowground biomass in all treatments. Lower air temperatures early in the growing season in the second year compared to those in the first year suggest that, rather than weather conditions, the higher application rate of plant biomass carbon increased $\mathrm{CH}_{4}$ emission during the season. Therefore, the significant effect of year on cumulative $\mathrm{CH}_{4}$ emission was because of the variation in applied carbon from plant biomass in this study. Sources of carbon for $\mathrm{CH}_{4}$ production in the early growing season originate mainly from organic carbon applied before rice cultivation [23]. Thus, results of this study show the importance of considering the total amount of incorporated biomass carbon from all three sources, i.e., green manure, weeds, and belowground biomass, for understanding the effects of green manure application on $\mathrm{CH}_{4}$ emission in paddy fields applied with green manure as basal fertilizer.

In this study, a similar amount of annual $\mathrm{CH}_{4}$ emission among different management of mid-season drainage might be due to the weather conditions during the mid-season drainage period. Especially in the second year, high $\mathrm{CH}_{4}$ fluxes and low Eh in all treatments after the starting mid-season drainage in the prolonged mid-season drainage treatments suggest that the high $\mathrm{CH}_{4}$ fluxes were due to anaerobic $\mathrm{CH}_{4}$ production under reduced conditions of soil caused by rainfall $\left(14 \mathrm{~mm}\right.$ for 4 days $^{-1}$ after the starting mid-season drainage). Itoh et al. [17] reported that the percentage of $\mathrm{CH}_{4}$ emission resulting from alternative water management strategies decreased with increasing differences in no-rain days during the mid-season drainage period between alternative and conventional water-management strategies. In this study, the percentage of $\mathrm{CH}_{4}$ emission resulting from prolonged mid-season drainage $(69.8 \%$ in the first year and $93.3 \%$ in the second year) was of a similar magnitude (68.5\% in the first year and $98.8 \%$ in the second year) to that estimated by the difference in no-rain days during the mid-season drainage period (4 days in the first year and 0 day in the second year) between prolonged and conventional mid-season drainage treatments using the equation provided by Itoh et al. [17]. This shows that $\mathrm{CH}_{4}$ emission resulting from prolonging mid-season drainage depended on rainy days during the mid-season drainage period even in this study site. Furthermore, $\mathrm{CH}_{4}$ emission may be reduced effectively when mid-season drainage is timed based on the weather forecast.

\subsection{Nitrous Oxide Emission}

Our study showed that the factors influencing $\mathrm{N}_{2} \mathrm{O}$ emissions in the fallow period have the biggest impact on annual $\mathrm{N}_{2} \mathrm{O}$ emissions. In the fallow season, higher $\mathrm{N}_{2} \mathrm{O}$ fluxes after incorporation of green manure but before transplanting rice seedlings and the significant positive correlation between $\mathrm{Rh}$ and $\mathrm{N}_{2} \mathrm{O}$ flux suggests that decomposition of organic matter increased $\mathrm{N}_{2} \mathrm{O}$ production. Increased $\mathrm{N}_{2} \mathrm{O}$ fluxes have been reported after incorporation of plant residue with low C:N ratio, e.g., legume crops [24,25]. In soil, $\mathrm{N}_{2} \mathrm{O}$ is produced mainly by microbial nitrification and denitrification [26]. The rates of these two processes are often determined by the amount of available organic matter, which supplies nitrogen for nitrification while its organic carbon works as an electron donor for 
denitrification. Toma and Hatano [24] and Lou et al. [27] reported that soil $\mathrm{N}_{2} \mathrm{O}$ flux was significantly positively correlated with soil $\mathrm{CO}_{2}$ flux. The lack of significant differences in $\mathrm{N}_{2} \mathrm{O}$ emission between treatments in the fallow season may be due to the high amount of weed biomass in all treatments. Because weeds could not be controlled once green manure was added, green manure application did not influence annual $\mathrm{N}_{2} \mathrm{O}$ emission. Higher emission of cumulative $\mathrm{N}_{2} \mathrm{O}$ later in the growing season in the first year compared to the second year resulted in the statistically significant effect of year on cumulative $\mathrm{N}_{2} \mathrm{O}$ emission in the late growing season and the entire growing season. The moderately reduced soil conditions demonstrated by lower Eh values and lower $\mathrm{CH}_{4}$ fluxes after mid-season drainage in the first year suggest that the soil condition was optimal for $\mathrm{N}_{2} \mathrm{O}$ production through denitrification. However, this study could not explain why $\mathrm{N}_{2} \mathrm{O}$ emission in CMG and PM was higher than that in PMG, especially just after mid-season drainage, under the different reducing conditions of soil demonstrated by changes in $\mathrm{Fe}^{2+}$ concentrations. Further studies, such as incubation experiments, may be required to understand this.

\subsection{Heterotrophic Respiration}

$\mathrm{CO}_{2}$ emission, defined as $\mathrm{Rh}$ in this study, includes $\mathrm{CO}_{2}$ released by decompositions of both green manure and other plant residues such as rice straw and weeds. Consequently, any effect of green manure application on annual Rh may have been confounded by the effect of weeds. Similar to cumulative $\mathrm{CH}_{4}$ emission, significant differences between treatments in cumulative $\mathrm{Rh}$ in the mid-season drainage period are because of prolonged mid-season drainage but not because of the higher potential for organic matter decomposition. Our study showed that organic matter decomposition after mid-season drainage was also affected by mid-season drainage prolongation. Although $\mathrm{Rh}$ generally increases with increasing soil temperature [6,28], lack of a significant relationship between Rh and soil temperature in the growing season implies that other factors, such as soil moisture, influenced Rh. Because of insufficient data on soil moisture in our study, the effect of soil water or related environmental conditions on $\mathrm{Rh}$ in the growing season in the second year was not analyzed.

\subsection{Net Greenhouse Gas Emission}

Because $\mathrm{GWP}_{\mathrm{CH} 4}$ was the main contributor to NGHGE, the strategy for reducing $\mathrm{CH}_{4}$ emissions may be effective in lowering NGHGE in paddy fields. Incorporation of weeds into the soil together with green manure can increase $\mathrm{CH}_{4}$ emission, and therefore, NGHGE. The regression equations in Figure $6 \mathrm{a}$ and the correlation between NGHGE and applied carbon from green manure and weeds indicate that application of $1.00 \mathrm{Mg} \mathrm{C} \mathrm{ha}^{-1}\left(3.77 \mathrm{Mg} \mathrm{CO}_{2} \mathrm{eq} \mathrm{ha}^{-1}\right)$ of biomass carbon from green manure and weeds increased $\mathrm{GWP}_{\mathrm{CH} 4}$ by $31.1 \mathrm{Mg} \mathrm{CO}_{2} \mathrm{eq} \mathrm{ha}^{-1}\left(687 \mathrm{~kg} \mathrm{C}^{-1}\right)$ and NGHGE by $37.6 \mathrm{Mg} \mathrm{CO}_{2} \mathrm{eq} \mathrm{ha}^{-1}$, although soil organic carbon and applied rice straw carbon were additional sources of carbon for $\mathrm{CH}_{4}$ production. Therefore, incorporation of plant biomass in the form of green manure and weeds into soil before rice transplanting offsets the benefits of carbon application and is not an effective strategy for reducing NGHGE in paddy fields. Although prolongation of mid-season drainage did not significantly reduce annual $\mathrm{CH}_{4}$ emissions and $\mathrm{Rh}$ in this study, $\mathrm{CH}_{4}$ emission, and therefore NGHGE, may be reduced when mid-season drainage is timed, based on the weather forecast, for increasing no-rain days. Although they are not effective strategies for mitigating global warming, both green manure application and prolongation of mid-season drainage may be acceptable for replacing chemical fertilizer to green manure while maintaining grain yield at the same NGHGE levels in rice cultivation.

\section{Conclusions}

This study showed that the best strategy for reducing $\mathrm{CH}_{4}$ emissions is to ensure emissions are lower early in the growing season, thought $\mathrm{CH}_{4}$ emission could be reduced effectively when mid-season drainage is timed based on the weather forecast. Although $\mathrm{N}_{2} \mathrm{O}$ emissions were larger 
in the fallow season and were dependent on the decomposition of organic matter incorporated, $\mathrm{N}_{2} \mathrm{O}$ emission did not influence the greenhouse gas effect in rice paddy fields because of the lower contribution of $\mathrm{N}_{2} \mathrm{O}$ to NGHGE. As an application of green manure with weed increases $\mathrm{CH}_{4}$ and $\mathrm{Rh}$, which offset the sequestrated carbon, the adaption of green manure utilization was not an effective strategy for mitigating global warming. However, both green manure application and prolongation of mid-season drainage can be acceptable for utilization of green manure instead of chemical fertilizer without changing global warming while maintaining grain yield.

Supplementary Materials: The following are available online at http:/ / www.mdpi.com/2077-0472/9/2/29/s1, Figure S1: Seasonal variations in $\mathrm{CH}_{4}$ fluxes in fallow season in the first (a) and second (b) years. Error bars represent standard deviations. SA, SI, and S, GM, and F represent straw application, incorporation, seeding, green manure and weeds incorporations, and fertilization, respectively, Figure S2: Seasonal variations in air temperature and precipitation (a), Eh (b), $\mathrm{Fe}^{2+}$ concentration (c) in the period of mid-season drainage in 2014, Figure S3: Seasonal variations in air temperature and precipitation (a), Eh (b), $\mathrm{Fe}^{2+}$ concentration (c) in the period of mid-season drainage in 2015, Table S1: Coefficients of the correlations between soil temperature at 5-cm depth and heterotrophic respiration ( $\mathrm{Rh}$ ) in fallow and growing seasons, Table S2: Cumulative $\mathrm{CH}_{4}$ emission (Mean $\pm \mathrm{SD}$ ), Table S3: Daily $\mathrm{CH}_{4}$ flux (Mean $\pm \mathrm{SD}$ ), Table S4: Cumulative $\mathrm{N}_{2} \mathrm{O}$ emission (Mean \pm SD), Table S5: Daily $\mathrm{N}_{2} \mathrm{O}$ flux (Mean \pm SD), Table S6: Cumulative Rh (Mean \pm SD), Table S7: Daily Rh (Mean \pm SD), Table S8: Spearman's rank correlation coefficients between greenhouse gases (GHG) and applied carbon, Table S9: Spearman's rank correlation coefficients between $\mathrm{N}_{2} \mathrm{O}$ emission and applied nitrogen, Table S10: Application rates of biomass carbon (Mean \pm SD), Table S11: Application rates of plant biomass and fertilized nitrogen (Mean \pm SD), Table S12: Number of panicle, 1000-grain weight, and brown rice yield (Mean \pm SD).

Author Contributions: Conceptualization, Y.T., O.N., S.N., B.P. and H.U.; methodology, Y.T., S.O., O.N., S.N. and H.U.; formal analysis, Y.T., N.N.S., S.N., K.A. and S.O.; investigation, Y.T., S.N., K.A., S.O.; resources, Y.T. and H.U.; writing—original draft preparation, Y.T., N.N.S., S.N. and K.A.; writing一review and editing, O.N., S.N., B.P. and H.U.; project administration, O.N. and S.N.; funding acquisition, N.N.S. and O.N.

Funding: This research received no external funding.

Acknowledgments: We would like to express appreciation to Yoichi Yamashita, Masataka Adachi, and Keiji Ishikake in the University Farm, Faculty of Agriculture, Ehime University.

Conflicts of Interest: The authors declare no conflict of interest. The funders had no role in the design of the study; in the collection, analyses, or interpretation of data; in the writing of the manuscript, or in the decision to publish the results.

\section{References}

1. Intergovernmental Panel on Climate Change (IPCC). Mitigation of climate change, introductory chapter: Synthesis report, summary for policymakers. In Climate Change 2014; Victor, D., Zhou, D., Ahmed, E.H.M., Dadhich, P.K., Olivier, J.G.J., Rogner, H.H., Sheikho, K., Yamaguchi, M., Grübler, A., Muvunkika, A., Eds.; Cambridge University Press: Cambridge, UK, 2014; Available online: https:/ /www.ipcc.ch/report/ar5/ wg3/ (accessed on 3 January 2019).

2. Food and Agriculture Organization of United Nations (FAO). FAOSTAT 2001. Available online: http: //www.fao.org/faostat/en/\#data (accessed on 3 January 2019).

3. Yagi, K.; Tsuruta, H.; Minami, K. Possible options for mitigating methane emission from rice cultivation. Nutr. Cycl. Agroecosyst. 1997, 49, 213-220. [CrossRef]

4. Minamikawa, K.; Yagi, K. Possibility of water management for mitigating total emission of greenhouse gases from irrigated paddy field. In Climate Change and Crops, 1st ed.; Singh, S.N., Ed.; Springer: Berlin/Heidelberg, Germany, 2009; pp. 307-328.

5. Akiyama, H.; Yagi, K.; Yan, X. Direct $\mathrm{N}_{2} \mathrm{O}$ emissions from rice paddy fields: Summary of available data. Glob/Biogeochem. Cycles 2005, 19, GB1005. [CrossRef]

6. Oomori, S.; Toma, Y.; Nagata, O.; Ueno, H. Effects of bamboo biochar application on global warming in paddy field in Ehime prefecture, Southern Japan. Soil Sci. Plant Nutr. 2016, 62, 553-560. [CrossRef]

7. Toma, Y.; Oomori, S.; Maruyama, A.; Ueno, H.; Nagata, O. Effect of the number of tillage in fallow season and fertilizer type on greenhouse gas emission from a rice (Oryza sativa L.) paddy field in Ehime, southwestern Japan. Soil Sci. Plant Nutr. 2016, 62, 69-79. [CrossRef] 
8. Sander, B.O.; Samson, M.; Sanchez, P.B.; Valencia, K.P.; Demafelix, E.A.M.; Buresh, R. Contribution of fallow periods between rice crops to seasonal GHG emissions: Effect of water and tillage management. Soil Sci. Plant Nutr. 2018, 64, 200-209. [CrossRef]

9. Pan, G.; Li, L.; Wu, L.; Zhang, X. Storage and sequestration potential of topsoil organic carbon in China's paddy soil. Glob. Chang. Biol. 2004, 10, 79-92. [CrossRef]

10. Nishimura, S.; Akiyama, H.; Sudo, S.; Fumoto, T.; Cheng, W.; Yagi, K. Combined emission of $\mathrm{CH}_{4}$ and $\mathrm{N}_{2} \mathrm{O}$ from a paddy field was reduced by preceding upland crop cultivation. Soil Sci. Plant Nutr. 2011, 57, 167-178. [CrossRef]

11. Becker, M.; Ladha, J.K.; Ali, M. Green manure technology: Potential, usage, and limitations. A case study for lowland rice. Plant Soil. 1995, 174, 181-194. [CrossRef]

12. Lauren, J.G.; Pettygrove, G.S.; Duxbury, J.M. Methane emissions associated with green manure amendment to flooded rice in California. Biogeochemistry 1994, 24, 53-65. [CrossRef]

13. Lee, C.H.; Park, K.D.; Jung, K.Y.; Ali, M.A.; Lee, D.; Gutierrez, J.; Kim, P.J. Effect of Chinese milk vetch (Astragalus sinicus L.) as a green manure on rice productivity and methane emission in paddy soil. Agric. Ecosyst. Environ. 2010, 138, 343-347. [CrossRef]

14. Toma, Y.; Maruyama, A.; Oomori, S.; Nagata, O.; Ueno, H. Study of rice (Oryza sativa L.) growth, yield, and quality, and variations of methane and nitrous oxide emissions from paddy field managed under organic farming. Bull. Exp. Farm. Fac. Agric. Ehime Univ. 2013, 35, 1-14, (In Japanese with English Summary).

15. Yagi, K.; Tsuruta, H.; Kanda, K.; Minami, K. Effect of water management on methane emission from a Japanese rice paddy field: Automated methane monitoring. Glob. Biogeochem. Cycl. 1996, 10, $255-267$. [CrossRef]

16. Zou, J.; Huang, Y.; Zheng, X.; Wang, Y. Quantifying direct $\mathrm{N}_{2} \mathrm{O}$ emissions in paddy fields during rice growing season in mainland China: Dependence on water regime. Atmos. Environ. 2007, 41, 8030-8042. [CrossRef]

17. Itoh, M.; Sudo, S.; Mori, S.; Saito, H.; Yoshida, T.; Shiratori, Y.; Suga, S.; Yoshikawa, N.; Suzue, Y.; Mizukami, H.; et al. Mitigation of methane emission from paddy fields by prolonging midseason drainage. Agric. Ecosyst. Environ. 2011, 141, 359-372. [CrossRef]

18. The Fifth Committee for Soil Classification and Nomenclature. Classification System of Japan 2017. The Japanese Society of Pedology. Available online: http://pedology.jp/img/Soil\%20Classification\% 20System\%20of\%20Japan.pdf (accessed on 6 January 2019).

19. Raich, J.W.; Tefekciogul, A. Vegetation and soil respiration: Correlations and controls. Biogeochemistry 2000, 48, 71-90. [CrossRef]

20. Toma, Y.; Fernandez, F.G.; Sato, S.; Izumi, M.; Hatano, R.; Yamada, T.; Nishiwaki, A.; Bollero, G.; Stewart, J.R. Carbon budget and methane and nitrous oxide emissions over the growing season in a Miscanthus sinensis grassland in Tomakomai, Hokkaido, Japan. GCB Bioenergy 2011, 3, 116-134. [CrossRef]

21. Intergovernmental Panel on Climate Change (IPCC). Chapter 8 Anthropogenic and Natural Radiative Forcing. In Climate Change 2013: The Physical Science Basis; Myhre, G., Shindell, D., Breon, F.M., Collins, W., Fuglestvedt, J., Huang, J., Koch, D., Lamarque, J.F., Lee, D.S., Mendoza, B., et al., Eds.; Cambridge University Press: Cambridge, UK, 2013; Available online: http://www.ipcc.ch/report/ar5/wg1/ (accessed on 6 January 2019).

22. R Development Core Team. A Language and Environment for Statistical Computing; R Foundation for Statistical Computing: Vienna, Austria, 2014; Available online: https://www.r-project.org/ (accessed on 6 January 2019).

23. Watanabe, A.; Yoshida, M.; Kimura, M. Contribution of rice straw carbon to $\mathrm{CH} 4$ emission from rice paddies using 13C-enriched rice straw. J. Geophys. Res. 1998, 103, 8237-8242. [CrossRef]

24. Toma, Y.; Hatano, R. Effect of crop residue C:N ratio on $\mathrm{N}_{2} \mathrm{O}$ emissions from Gray Lowland soil in Mikasa, Hokkaido, Japan. Soil Sci. Plant Nutr. 2007, 53, 198-205. [CrossRef]

25. Shimotsuma, M.; Uchida, Y.; Nakajima, Y.; Akiyama, H. The effects of rice (Oryza sativa L. ssp. japonica) husk biochar on nitrogen dynamics during the decomposition of hairy vetch in two soils under high-soil moisture condition. Soil Sci. Plant Nutr. 2017, 63, 178-184. [CrossRef]

26. Butterbach-Bahl, K.; Davidson, E.A.; Smith, K.A.; Smith, P.; Melillo, J.M.; Dentener, F.; Crutzen, P.J. Nitrous oxide emissions from soils: How well do we understand the processes and their controls? Philos. Trans. R. Soc. B 2013, 368. [CrossRef] 
27. Lou, Y.; Ren, L.; Li, Z.; Zhang, T.; Inubushi, K. Effect of rice residues on carbon dioxide and nitrous oxide emissions from a paddy soil of subtropical China. Water, Air Soil Pollut. 2007, 178, 157-168. [CrossRef]

28. Boone, R.D.; Nadelhoffer, K.L.; Canary, J.D.; Kaye, J.P. Roots exert a strong influence on the temperature sensitivity of soil respiration. Nature 1998, 396, 570-572. [CrossRef] 